\title{
TWO CASES OF ACUTE ASCENDING PARALYSIS, WITH AUTOPSY.
}

\author{
BY Johs Jenks Thoues, A.M., M.D.,

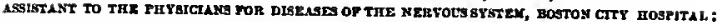

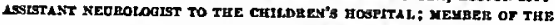 \\ AMERTCAN NEUROLOGICAL ASSOCHATON, MTC. \\ (Fron the Pathological Laboratory of the Baston City Iraspital.)
}

Is 1859 the French physician Landry published his paper describing a disease which, until that time, bad heen confounded with others. His original description of this disense was that it was an acute paralysis heginning in the legs, ascending to the arms, and later involving the muscles supplied from the medulla. This paralysis was unaccompanied hy any marked disturhance of sensation, although he stated that, at times, slight parasthesin might be present. The sphincters were, usually unaffected. He also stated that the paralyzed muscles retained their cxcitability to the faradic current, that the mind remained clear, and that fever was slight or absent. Another criterion which he gave was that after death no lesions were to be fonnd in the nerrous system, and that the careful microscopic examination of tbe cord was negative.

Since that time many cases have heen reported as examples of this disease, many of which have varied considerably from the original picture as descrihed by Laindry.

The two following cases present a picture very closely resembling the original case described by Landry, and are reported together, because in hoth cases pathological examinations were obtained and made. I am indehted to Dr. Sears for permission to use the clinical notes of the first case, and to Dr. Folsom for those of the second case; also to Dr. Bullard for permission to use notes which he had made. I also wish to express my thanks to Dr. Councilman, who kindly allowed me to examine the material and aided me in the work.

CASE I.-N. G. Genale, aged thirty-six years; single. She entered the Boston City Hospitnl on August 29, 1896. She was horn in Vermont, and her occupation was that of a housekeeper. One hrother died of phthisis. Her mother was said to he very nervous, and died suddenly three years ago of heart disease. The futher wns alive and well. The patient was never very strong, and lost much time from school. She had diphtheria and scarlatina when a child, and measles and mumps two years ago. Since that time she had been well, until last March, when she hegan to run down. Two years ago, after the shock of the death of her mother, she had a period of numhness in the right arm, lasting several weeks. This was not accompanied by any loss of strength. Her appetite was good. She denied the use of alcohol and morphine, and drank no tea nor coffee. There was no venereal history. Four 
years ngo she had nn isehio-rectsl nhsces, resulting in a fistuln which remained unhealed.

Present Trouble. In March, 1896, she took a severe cold, and since that time hnd not felt so strong. She had lost twelve pounds, and felt weak, and was easily tired. She had considerahle dyspnoea at times, nud complained that "the food was heavy on her stomach " and caused distress. The howels had been much constipnted. The nppetite was good. The catamenin wrere regular nnd without pnin. She hnd never been suhject to headache, hut nhout a year ngo her eyes pnined her, nnd she procured glasses, nnd had no trouhle after that. She had heen much confined to the house. On August 5th she had nn nttnck of indigestion. She went to hed nnd took salts nnd calomel. Torrnod evening of thnt day she noticed $n$ weakness in her legs, and thnt she hnd difficulty in going up stairs. She went to hed feeling perfectly well, except for this weakness, hut on waking in the morning she found that she could not move her legs nt all. The legs felt numh and dead, and they were somewhat painful to preseure. The howels had moved once after the calomel, hut not after that (paralysis of the rectum?). There was also retention of urine.

Physical Examination. The pntient was hright and intelligent. She was well developed nnd had good color. The pupils were clear, regular, normal in size, nnd reacted to light and with nccommodation. The externnl ocular museles were normal. The tongue was moist, with $n$ white cont, and was protruded in the median line. The pulse was regular, of good strength and volume.

Heart: The area of cardinc dulnese was not enlarged, the apex was in the fifth interspace, three and three-quarter inches to the left of the median line. The heart's action was regular. The first sound at the aper was roughened.

Lungs : The resonance and respiration were good throughout. The area of hepatic dulness extended from the sixth rib to the costal border.

The aren of splenic dulness was not enlarged.

The ahdomen was tympanitic, not tender.

There was slight power of flexion of both legs. The toes and feet could he moved slightly; those of the left foot more thn the right. The pntellar and plantar reflexes were absent. The sensation was nowhere affected. There was considerahle tenderness on pressure in the calves of the legs. In the upper extremities the grasp was weak on hoth sides, the left more so than the right. What muscular power remained in the nrms was greater on the right side. The sensation here was normal, as also on the trunk. There was no tenderness in the upper extremities on pressure.

On August 14th $n$ gmull area of hronchial hreathing was noted just nhove the angle of the scapula and just outside of the median line in the left back. There was no cough and no expectoration. There had heen considerahle dyspnor. The temperature had fallen somewhat, hut the respirations had increased in number. The howels moved only hy enemata. The urine was passed spontaneously. Since entrance the strength of the right arm had diminished. On this day she could flex nnd extend the forearm slightly, hut could not raise the arm from the hed. The only movement remaining in the left arm was a slight movement of the fingers. There was ahsolutely no movement possible of the lower extremities. The tenderness upon pressure in the legs had diminished. 
The examination of the urine on August 14th showed it reddish in color; specific gravity of 1.018 ; nlkaline in reaction; chlorides diminished; the urea normal in amount; albumin, a trace. Bile pigments and sugar were absent. The sediment showed quantities of triple phosphates, some pus, a little abnormal hlood, a few questionahle granular casts, and several large round cells.

On August 18th it was noted that the tenderness in the arms and legs upon pressure had returned. The patient could still flex the left arm feehly. Other movements were impossihle. There was incontinence of urine.

A second examination of the urine, made upon Algust 19th, was as follows: Color, light; specific gravity, 1.017 ; reaction neutral; chlorides diminished; urea normal ; a trace of alhumin was present; hile pigments and sugar were ahsent. The sediment consisted chiefly of pus, with a ferr small round cells, a few triple phosphates, hut no casts were found.

On the 19th there ras paralysis of respiration. On the $22 \mathrm{~d}$ it was noted that she had periodical attacks of difficult hreathing, when the throat seemed to choke up and suffocation threatened. She had had two severe attacks of this kind, both of which passed off. All the muscles of respiration were noted upon this day as being inactive except the diaphragm. She complained that she could not get into a comfortahle position, and she had to be moved continually.

On the 23d it was noted that there was slight movement possible of the left wrist, and that she could fex and extend the fingers of the left hand. The right arm could he slightly ahducted, hut could not he moved backward or upward. All movements of the right forearm and wrist wero passihle. Thero was complete paralysis of all the muscles of the lower extremities, of the ahdominal muscles and the muscles of respiration, with the exception of the diaphragm. There was no paralysis of the face, tongue, or pharyns. The sensation everywhere was nornial. There was considerahle tenderness in the culves and slight tenderness in the thighs upon pressure. The glands in the neck were enlarged. The liver could be felt at the level of the umbilicus and could be seen to move with the movements of the diaphragm. The patient was unahle to cough or to make forced expiration.

On August 24 th at 8.30 A.st. the patient was found hreathing with difficulty, the face was cyanotic, hut she had no difficulty in speaking. The nurse reported that at 7 A.s. the patient had seemed as usual. From 8.30 s.sr. the dyspncea increased gradually, the pulse hecame weaker, and she died at 11.50 s.s.

Chart.

\begin{tabular}{|c|c|c|c|c|c|c|}
\hline \multirow[b]{3}{*}{ 9th, } & \multicolumn{2}{|c|}{ Teroperiture. } & \multicolumn{2}{|c|}{ Pulse, } & \multicolumn{2}{|c|}{ Hesplratíon. } \\
\hline & A.M. & P.K. & A.4. & P.M. & A.m. & F.x. \\
\hline & $\cdots$ & $102^{\circ}$ & .... & 95 & $m$ & 24 \\
\hline 10th, & $101^{\circ}$ & 101.5 & 94 & 95 & 23 & 24 \\
\hline 11th, & 101 & 101 & 90 & 94 & 24 & 20 \\
\hline 12th, & 99.4 & 99.8 & 100 & 100 & 24 & 24 \\
\hline 13th, & 99.8 & 100.8 & 100 & 100 & 24 & 28 \\
\hline 14th, & 100 & 98.5 & 100 & 90 & 40 & 28 \\
\hline 15th, & 98.4 & 98.4 & 96 & 90 & 32 & 28 \\
\hline
\end{tabular}




\begin{tabular}{|c|c|c|c|c|c|c|}
\hline \multirow[b]{2}{*}{ 16th, } & \multicolumn{2}{|c|}{ Tempenture. } & \multicolumn{2}{|c|}{ Palse. } & \multicolumn{2}{|c|}{ Respiration. } \\
\hline & $\frac{1.4 .}{98.2^{\circ}}$ & $\begin{array}{c}\text { P.uc. } \\
98.4^{\circ}\end{array}$ & $\frac{14 x}{80}$ & $\begin{array}{l}7 x \\
72\end{array}$ & $\begin{array}{l}\text { A 3x. } \\
24\end{array}$ & $\begin{array}{l}\text { P.M. } \\
24\end{array}$ \\
\hline 17 th, & 98.4 & 99 & 72 & 70 & 24 & 24 \\
\hline 18th, & 99 & 98 & 80 & 84 & 24 & 24 \\
\hline 19th, & 98 & 99 & 80 & 84 & 28 & 26 \\
\hline 20th, & 98.4 & 100 & 100 & 104 & 25 & 26 \\
\hline 21st, & 98.2 & 98.8 & 88 & 100 & 24 & 24 \\
\hline 22d, & 99.2 & 100 & 100 & 110 & 36 & 32 \\
\hline $23 \mathrm{~d}$, & 98.6 & 98.4 & 114 & 112 & 32 & 28 \\
\hline 24th, & 98 & ........ & 140 & $+\ldots . .+$ & 44 & $\cdots$ \\
\hline
\end{tabular}

Autopsy, August 25, 1896. The hody was that of a roman of about forty years of age. Body length $162 \mathrm{~cm}$; fairly well developed; poorly a ourished. Ahdomen markedly disteaded. The feet in the position of extreme dorsal flexioa. Fingers sharply and apparea tly forcibly flexed on the metacarpals. Suhcutaneous fat much diminished.

The intestines, particularly the large intestiaes, were widely distended, containing much gas with considerahle feces.

The appendix was $8 \mathrm{~cm}$. long, extending down behind the ileum, the tip overhangiag the pelvis; it was free throughout its whole extent.

The heart weighed 220 grammes. The muscle was deep red in color. The valves and cavities were normal.

The left lung wras adherent over a small portion of the upper lohe by old adhesions. In the lower lohe of the left lung a large area was appareatly completely solidified; on section this was mottled, yellow and deep red; the bronchi in this region were filled with a yellow, purulent material. The right lung was a ormal except for considcrahle fluid at the hase.

The liver weighed 1020 granmes. It was normal in color, and on section aormal in a ppearance.

The spleen was fabhy, of a grayish-red color, on section rather soft, the pulp normal, weight 80 grammes.

The kidneys together weighed 260 grammes. The cortex was much thianed, in parts being from one-third to one-half $\mathrm{cm}$. thick. The whole kidney was deeply injected, the glomeruli standiag out as hright red points. The capsule was rather adherent, and some of the cortical suhstance adhered to it when it wiss torn off.

On the right side in froat of the uterus there was a large, hard, pedunculated tumor. On section this was white and firm. Otherwise . the uterus and appendages were aormal.

The hladder contained a small amoun t of thick, yellow, cloudy uriae.

The mucous memhraae of the hlsdder was much injected. Scattered over the surface were promiment masses of good-sized vessels, and the tissue ahout these nreas was deeply injected.

The aorta had scattered over its surface many small yellow, opaque, promineat areas.

The aerves of the lumhar and sacral plexus, as well as the paeumogastric, oa either side, were removed for microscopic examiastion. No gross change was appareat. The dura of the cord was distended with considerahle clear, rather thick, serous fluid. No gross lesions were apparent in the cord.

Bacteriological Report. Cultures from the heart, liver, and spleen 
vere sterile. Those from the kidney gave coloa hacillus and liquefying organisms. Cultures from the spinal cord showed liquefying organisms.

The stains used in the examination of thess two cases were those of Nissl and Leahossek for the ganglion cells; Weigert's and Pal's myelin shenth stains, phosphomolyhdic acid hæmatoxylin, bæmatoxylin and eosine; Van Gieson's picric ncid nad acid fuchsin stain; Mallory's methods of stainiag the neuroghia fibres with gentian-violet, and phosphotunstic acid hainatoxylin; and Weigert's and Loeffer's stains for micro-orgaaisms; together with Marchi's method of staining for fat. For the peripheral nerves, Marchi's and Weigert's methods nnd hematoxylia a ad eosia were the stains used.

After hardeaing, the nnterior portions of the gray matter showed darker in color than the remaiader of the gray matter of the cord.

Sectioas of the lumbar cord stained hy Pal's method showed the white matter of the cord with low power normal, except that the small bloodvessels eatering from the membranes isere dilated and filled with hlood.

There was no marked degeneration in any of the nerve-tracts. The posterior nerve-roots were normal. The anterior nerve-roots showed very marked degeaerations, fully two-thirds of the fihres having disappeared. The posterior borns of the gray matter were perfectly normal, both as to nerve-cells a ad fibres. The anterior horn oa the right sids was totally replaced by an npprently homogeneous grayish area. In the left horn the coadition was the same, but there remained ua affected a anall portion toward the anterior fissure, which was about oae-fourth of the total anterior horn.

On examination with \& high power there were seea in the white matter of the cord numerous single nerves which were degeaerated. Some of them were greatly swollen, the myelia ahenth of ten very thia aad more or less hroken up, and occasionally there were drops of myelin withia the myelia shenth. The posterior nerve-ronts showed very few degeaerated fihres. Occisionally one was seea where the myelia sheath was thianer than normal. In the a aterior nerve-roots a greater part of the nerre-fihres had disappeared. Of those that remaiaed nhout onelialf appeared normal. In the others the myelia sheath was reduced to a mere thread, nnd large, irregular drops of myelin yere pregent. In the posterior horns of the cord the nerve-fibres nad cells appeared unchnaged. Ia the anterior horns the portions which with the low power preseated the homogeaeous appearance were seen to be made up of a mass of smaller aad larger cells, some coataiaing sharply staining nuclei, otbers with iadistiact auclei, and here a ad there in the left horn near the horders of the degeaerated area were large, irregular masses of myelin and occasional cells staiaing $\mathrm{n}$ homogeneous hrown, nppareatly degenerated nervecells, oaly oas or two of which show any signs of $n$ nucleus remaining. Maay of these small cells throughoat the degenerated area contained irregular drops of myelin staining hlack, aad at the horders of the area were occasional large masses of myelin or remaias of $n$ degenerated myelin sheath.

Sections of the lumbar cord stained with hamatoxylin and eosin shoved dilatation and injection of the smull hloodvessels extending into the cord, hoth those from the periphery of the cord as well as those from the naterior fissure. In many of the vessels the perivascular lymph space was entirely filled with large and small lymphoid cells, which also ia filtrated the wall? of the vessel itself. 
The vessels of the posterior column of the cord and of the posterior nerve-roots showed only very slight infiltration of the perivascular space. Many of them were entirely normal. In the anterior nerve-roots nhout the smaller vessels there was considerahle infiltration with round cells, and round cells were seen with greater frequency than nomal nli through the substance of the nerve-root. These cells were usually small, with imall, round, deeply-staining nuclei, hut many of them had large, single, faintly-strining nuclei, oval or round in shape, nearly filling the cell body.

The white matter of the cord in the lateral columns showed, aside from the infiltration ahout the hloodvessels, practically normal appearnnces. Some of the small vessels contained an accumulation of leucocytes, from which npparently a slight emigration into the surrounding tissue was taking place. This was not generally true. In the majority of the vessels there was no such accumulation of the leucocytes, but there was a small, round-cell infiltration of the vessel walls and of the perivascular lymph spaces. This infiltration nhout the vessels was more marked in the case of the arteries. Most of these cells were small, with round, very deeply-staining nuclei, almost filling the cell. Others, fewer in number, with slightly grannlar protoplasm, contained a round or oval granular nucleus which stained inteosely. Leucocytes were ferv in number. There was no hemorrhage nbont the vessels in the substance of the cord.

The degenerated partions of the anterior horn of the gray matter appeared totally disorganized. Only occasionally in tho horders of this area could be seen the remains of nerve-cells. These were small, shrunken, homogeneous-staining masses of protoplnsm, occasionally showing indications of processes. In a ferr of them, ose purtion, taking the hamatoxylin more deeply than the rest, showed the indistinct remains of the nucleus.

The degenerated area itself consisted of $\mathbf{n}$ disorganized mass of cells and detritus. These cells varied in size, some of them being small, round, lymphoid cells, with round, deeply-staining nuclei, surrouaded hy a narrow hand of clear protoplasm. Other cells were similar to the large lymphoid cell with nucleus rather small in relation to the cell hody, and the nucleus divided into $n$ number of granules with more or less reticulum hetween them. These cells were the plasma cells of Unna. The protoplasm was finely granular, and with methylene-hlue stained more deeply than that of other cells. They were found chiefly in the vicinity of the vessels, hut also to a certain extent scattered nmong the other cells. Very rarely there were seen large round cells with irregular, less deeply-staining nuclei similar to those of leucocytes.

The small round cells similar to lymphocytes were comparatively few in number. There were nlso scattered ahout a considerable numher of large vesicular cells; in some of them the nucleus was round, in others similar to that of a leucocyte. These cells were the ones spoken of helow as containing the drops of myelin nnd fat. There were numerous larger and smaller hyaline masses scsttered through this area, sometimes drawn out, sometimes in rounded masses, evidently the remains of nervecells and nerve-fihres. One of these masses was found partially surrounded hy $n$ large vesicular cell. Occasionally throughout the whole of this nrea large vesicular cells were seen filled with drops of fat and myelin, as was shown hy the sections stained according to Pnl nnd 
Mnrchi. These sectious also slowed the presence of fnt and inyelin drops in a lnrge portion of the smnller lymphoid cells. Scattered throughout this nrea were masses of myelin or fnt not contnined in cells. Ocensionally nhout one of these drops of myelin could he seen $n$ portion of a degenerated myelin eheath. This same section showed thnt the degeneration of nerve-fihres in the lateral columns, while involving numerous nerve-fihres, was still moderate in amount. The same was true of the posterior nerve-roots. The auterior nerve-roots showed signs of very extensive destruction of the myelin sheaths.

Sections stained with phosphomolybdic acid showed nearly normal conditions in the white matter of the cord nnd of the posterior horns of the gray matter. There were almost no nerve-cells in the anterior horn.

Sections stained hy Nisl's method showed the presence of perfectly normal nerve-cells in the posterior horns; while in the anterior horn on the right side in one section there were only four nerve-cells, two of which were irregulnr, round nuasses of protoplasm containing no granules, with intensely-stnining nuclei. The other cells showed the nucleus nnd nucleolus somewhnt more plainly; the granules were fairly distinct, hut sinnller thinn normnl. But one or two processes could he seen to he given off from the cells, and these could he traced hut $n$ very ehort distnnce from the cell-hody, apparently ending ahruptly.

In one of these sections $n$ cell lying in the wall of a vessel showed in its nucleus a karyokinetic figure.

Sections of the lumhnr cord stained by Mallory'e ofain for neuroglia showed no increase in the neuroglia anywhere in the cord, and practically complete ahsence of the neuroglia fihres in the degenerated nreas of the anterior hora.

Sections of the dorsal and cervical cord ehowed practically the same conditione that were seen ia the lumhar regions. The degeneration of the anterior nerve-ronts was fully as extensire as in the lumbar sections, while the posterior nerve-roots ehowed practically normal conditione.

In the dorsal cord the dieiategrated area in the anterior horne of the gray matter, the iafiltration of the hloodvessels of the cord and of the nnterior nerve-roots was fully as extensive as lower down. In the cervical cord, the right anterior root ehowed oaly a small nren of degeneration in its anterior portion. The left horn ehowed more extensive degeneration involving the anterior and median portions of the horn from its hase down to the centre of the gray commissure. Infiltration nhout the hloodvessels of this portion of the cord wns less extensive than lower down, hut many of the vessels werc widely dilnted and filled with red hlood-corpuscles, with compnratively few leucocytes, while the infiltration of the wnlls of the ressel was extensive in Eome portions and very little in others.

Sections of the cord at various plnces stained by Weigert nnd Loeffler's methods for micro-organiens failed to show the presence of any organisms.

Sections of the sciatic nerve stained by Marchi's method were in general normal. The Tongituantal sections stowed-slight degeneration of the myelin sheath. Cross-sections of the nerve showed similar degeneration, but not very extensive.

Sections of the pneumogastric nerve showed marked fatty degeneration. In the longitudinal Eections there was a great dentof fat in the myelin sheath. In addition, the sheath was swollen nud in many places vor. 116, vo. 2,-1UGUar, 1898. 
had $n$ grayish tinge. The axis-cylinder was also swollen and beaded. In places where the nerve-shenth was most degenerated the axis-cylinder was not nppareat. In other places where the myelin sheath was swollen and grayish it was difficult to make out the nxis-cylinder. Cross-sections of this nerve showed in places swollen nerve-sheaths without axiscylinders. Other nerve-fihres showed fat-granules often within the myelin sheath and lying close to the axis-cylinder. The nerves in which the myelin shenth was grannlnr, grayish, nnd swollen, here showed more evidence of the presence of fat-glohules than was shown in the longitudinal sections. In the anterior crural nerve the nerve-sheaths occusionally showed elightly degenerated fihres, hut these were less numerous than in the other nerves. The phrenic nerre showed $n$ much less degree of degeneration than the pneumogastric. The nerve-fihres replaced hy fat-granules were much less numerous, hut in the grayish swollen nerve-sheaths swollen and beaded axis-cylinders were often evideat.

Sections of the pneumogastric nerve stained with hrmatoxylin showed the axis-cylinder of many of the fihres distinctly swollen and headed. The hloodvessels were injected everywhere, and in the sherth of the vessels there were numerous round cells and, in places, slight accumulations of rouud cells, which often extended from the connective tissue slightly into the nerve.

Sumisiary of Microscopic Exaunatrov. 1. Acute inflammatory exudation of the anterior horns of the gray matter, with parenchyma. tous degeneration of the nerve-cells and processes.

2. Infiltration of perivascular lymph spaces and dilatation of vessels of the anterior horns.

3. Moderate infiltation ahout the vessels of the posterine horns and of the white matter of the cord.

4. Slight parenchymatous degeneration of the nerve-fibres of the white matter of the cord.

5. Slight degeneration of the posterior nerve-roots and marked degeneration of the anterior nerve-roots.

6. Pnrenchymatous degeneration and perivascular infiltration of the peripheral nerves.

7. A hsence of micro-organisms in sections and cultures.

Anatomical Diagnosis. Broncho-pneumonia of left lung. Chronic, diffuse nephritis, Arterio-sclerosis of aorta. Myoma of uterus. Acute anterior poliomyelitis.

CAsE II.-V. F., male, aged thirty-five years, married, was horn in Italy, and his occupation was that of $n$ lahorer. The patient entered the Boston City Hospital, October 5, 1896. His family history was negative. He had been four yenris in Boston. He denied the use of alcohol, and, so far as known, had heen well and strong up to twelve days hefore. At that time he hegan to he trouhled hy numbness and wenkness in his legs. This increased for two dayg, at which time he was ohliged to give up work and go to hed. He had very little pain, nnd no nausea or vomiting. He was gaid to have had one attack of dyspnoea on the day of his entrance into the hospital. He ascrihed his trouhle to exposure to cold nnd rain. His chief complaint was numhness in the legs.

Physical Examination. The patient was n well-developed nnd nourished man. The pupils were equal in sizc and reacted to light. The 
tonguc was protruded straight, nnd was uooist, with a slight coating. The pulse was regulnr, of good strength and volumc. The area of cardiac dulness, the cnrdiac sounds, and nction were all normal.

The resonance over the luags was good throughout. The respiration everywhere was accompanicd hy squenking and sonorous railes, and a fer coarse, moist rüles.

The nreas of liver and splenic dulness were normal. The ahdomen was negative. There was marked paralysis of hoth lower extremities, the only motion possible heing a slight flexion of the knees. There wras also marked weakness of the muscles of the trunk and neck. The head could be rotated, hut not raised. There was a very slight power of contraction of the ahdominnl muscles, nnd $n$ marked loss of power in all the muscles of the upper extremities. The arms could be raised very slightly only; the grasp was weak. The patellar reflexes were nbsent, is were also the reflexes of the nrms. The plantar refexes were present, but very slow. The cremnsteric and nhdominal refleses were normal. The sensntion for pain was every where normal. There was no tenderness along the spine or over the great nerve-trunks.

Examination of the urine made Octoher 6th showed the color normal ; the specific gravity 1.025 ; ncid reaction; chlorides incrensed. Albumin, bile pigments, and sugar all absent. On Octoher 7 th it was noted thnt the patieat complained of no pain, and took his nourishment well. There was no reteatioa of urine, but the bowrels bnd not moved. In the nigbt he had an attack of dyspnoea, and bad been unable to expel the mucus from bis tbroat. That morniag marked conjusactivitis was noted. At $6.300^{\prime}$ clock that evening he began to have severe dyspnoa, the pulse hecamo wenk, and the extremities cold. He was given strych. nine subcutaneously, but died at 7 o'clock.

\begin{tabular}{|c|c|c|c|c|c|c|}
\hline & & & IART. & & & \\
\hline & Terr & ure. & & & Res & ou. \\
\hline & L.y. & P.Xx. & A.4. & P.U. & A.4. & P.2. \\
\hline Oct. 5th, & 98.6 & 98.6 & 96 & 88 & 24 & 24 \\
\hline Gtb, & 98 & 98.4 & 80 & 92 & 20 & 24 \\
\hline 7 th & 97.8 & 97.2 & 124 & 120 & 24 & 32 \\
\hline
\end{tabular}

Autopsy, October 8, 1896. The body was that of a man ahout forty years of age. Body small, tolerably well nourisbed. Rigor mortis extremely well marked.

Sealp normal. Skull of ordinary thickness; dura not adherent; rather hypersmic. The inner meninges and the hrain itself hyperemic.
The gray matter of the hrain had a pinkish hue on section. The hyper-
xmin seemed to he best marked in the mia seemed to he best marked in the great ganglia at the base.

Suhcutnneous fnt normal in amount. Ifuscles well developed. The spinal canal was opened in its entire extent, nnd the cord, togetber with most of the posterior nerve-roots, remored. A number of the spinnl ganglin were removed with cord. The meninges of the cord were hyperamic. The cord itself was well preserved, somewhat byperxmic; nothing ahnormal in the nerves. Long pieces of encb sciatic nerve were

In the posterior portion of hoth lungs, espccially the left lung, and in this also along the anterior lateral border, there nre numerous dark 
nreas from which occasiounlly sone pus could he expressed from the hronchi. Others seemed to be due entirely to hemorrhage. In the hronchi there was some muco-purulent exudation.

Heart of ordinnry size, weight 240 grammes; valves normal ; myocardium very dork.

Spleen, weight 175 grammes; very lax, slightly enlarged; on section, of pale hrownish color; Mnlpighinn hodies not visihle; trahecula slightly increased. The kidneys together weighed 175 grnmmes. Both of about the same size; both intensely hyperxemic; markings normal; capsule easily stripped off.

Liver, weight 1200 grammes. Dark red ; on section, hyperemic ; markings faintly visible. The fall-hlndder contained thin, dark bile.

The adrennl glands normal. Pancreas hyperemic and extremely soft.

The mucous membrane of the entine intestinnl cannl normal, enve just ahove the ileo-crecal valve, where there was very slight enlargement of the follicles. The mesenteric glands were enlarged and reddened.

Arteries and veins normal.

Bacteriological Examination. Cultures from heart, liver, spleen, kidneys, meninges of hrain, nnd spinnl cord were sterile. Four cultures were taken from the brain, three from the meninges of the hrain, nnd one from the spinnl cord. Three of these (two from hrain and one from meninges) showed no growth. Dilutions and replants from the others showed nothing but saprophytes (n spore-forming hacillus), a large coccus, and a large diplococcus.

Dficroscopical Examination. Sections of the lumhnr cord stained according to Pal showed no changes in the white sections of the cord. The fibres and nerre-cells of the gray matter appenred normal, the nerve-cells heing present in normal number and showing no changes hy this stain. The nerre-fihres in the gray matter were also unchanged. The bloodvessels in the anterior horn appeared distended and filled with hlood. There was no infiltration of their walls, hut the perivasculnr lymph spnces of some of them vere dilated. The posterior nerve-roots were normal. The anterior nerve-roots shomed_degeneration of a considerahle number of nerve-fibres.

Sections stained with phosphomolyhdic acid showed no diminution of nerve-fihres and no chnnges in the nerve-cells. The axis-cylinders of the anterior roots were occusionnlly nhsent, while others stained poorly.

Sections stnined with hemntoxylin and cosin showed no chnnges heyond the dilatation of the vessels in or near the gray mntter of the cord. These vessels contained generally red hlood-corpuscles and only $\mathrm{n}$ fcr leucocytes. There was no infiltration of the wnlls of the vessels. In others of these vessels there was an accumulntion of small round cellg, with deeply-staining nuclei.

Sections stained for neuroglin showed no increase of this substance anywhere in the cord.

Sections stnined with Nissl's strin showed thnt in a large majority of the cells of hoth anterior horns there was a diminution of the protoplasmic granules. In some cells there remnined in the periphery of the cell nenriy normal granules, while the central portion of the cell showed a slightly yellowish homogeneous nppenrance dotted with a few very small, irregular granules, with no eigns of nucleus or nucleolus. In other cells the nucleus could not be made out, hut the nucleolus stained 
indistinctly, and the whole hody of the cell was filled with very fine granules, like dust, with very few or no normal granules. Those which were present were only seen at the periphery of the cell. Other cells showed finely granular detritus at one end of the cell, while the other was clear, showing no granules whatever, with no signs of nucleus or nucleolus anywhere to be seen. The cell-processes even of these degenerated cells appeared normal. The cells seen in other portions of the gray matter showed normol granules and nucleus nnd nucleolus. In the onterior horn, along with these changed cells, were others which appeared nearly or quite normal, the only thing noticeahle in them heing an irregularity in the size of the graoules.

Sections stained according to Weigert and Loeffler showed no microorganisms present in the substance of the cord. Sectinns of the dorsal and cervical cord nt various places showed ths same chonges in the large motor cells of the nnterior horns, fully ooe-half of the cells of the dorsal region of the cord heing affected, though to a slighter degree than the cells of the lumhar cord. Changes in these cells again hecame more marked and involved a greater number of the cells in the cervical portion of the cord.

Sections of the medulla stained hy Nisl's method showed no changes in the nerve-cells, the granules heing sharp and clear, the nucleoli strining well, nnd the nerve processes oppearing n ormol. In the sections of the cortex of ths hrain, in some of the lniger nerve-cells the granules were smaller than normal aod more or less irregularly scattered throughout ths whole cell-hody. No cells were seen where ths granules had disappeared or where thsy had heen replaced hy granulsr dust. The sinaller cells of the cortex appeared normal.

Sections of the dorsal and lumbar spinal ganglia stained hy Nisal's method showed the ganglion cells in gencral quite n ormol. Occasionally ons was seen cootaining o vacuole, whils in all of them ths protoplasmic granules were rather smoll. Otherwise the sections of these ganglia oppeared perfectly normal.

Sections of the left anterior crural nerve treated by Morchi's method showed numerous fot-globules within the nerve-sheaths. Io places the perve-sheath was entirely replaced hy fat-globules. The axis-cylinder had completely dissppeared. Other fihres shnwed a hrownish discoloration of the nerve-sheath, which was more granular and swollen than normal, while the axis-cylinder was swallen and beoded. These changes were seen to a greater or less extent in more than half the fihres in the section.

Cross-sections of the same nerve showed drops of fot in the myelin sheath, in other places occupying the centre of the sheath, the position of the axis-cylinder which had dissppeared. Other fihres showed $n$ thin line of fat in the myelin sheath. The nerve-fibres varied somewhat in size, hut the greatly swollen ones were comporatively few in numher, and in these the axis-cylinder could not he mode nut at all, the centre staining a homogeneous gray color, or the whole nerve-fihre heing represented hy o single large glohule of fot.

Ths leftsciatio-nerve, in longitudinal section, showed the same condition as the nnterior crural nerve, hnt affecting 0 greater number of fihres, and the fat-drops were mnch more numerous; seldom was a nerve-fibrs seen which was free from them, while the headed appearance of the axis-cylioder was seen in $n$ greater numher of them. 
Cross-sections showed comporatively few of the nerve-fihres unaffected hy cbanges. The mujority of them were reploced by fat-glohules, while most of the remainder were stained a grayish brown.

The right sciatic nerve showed similar chonges, which were as well marked and fully as extensive as in the left eciotic nerre, fully threefourths of the fihres in the cross-sections heing more or less extensively degenerated.

Sections of the left sciatic nerve stained with hæmatoxylin showed an increase of the coonective-tissue nuclei tbroughout the nerve, nnd considerahle infiltration of small lymptoid cells in the wolls of the vessels and nbout them, both outside and within the nerve-hundles proper. In cross-sections about one-holf of the axis-cylinders could he seen, hut many of those present were much smaller tbon normal, while others were greatly ewollen, und in mony cases the axis-cylinder could not be made out. Infiltrution of the vessel wolls was well morked in this section also.

Sections of the left nnterior crural und right sciotic nerves stained witb hamatoxylin nnd eosin showed ehanges similar to those descrihed in the left scintic nerve, tbough in the former nerve the proliferation of nuclei nnd the infiltration of the vessel walls were much less marked.

In sections of the left mnterior crural nerve, etained with Weigert's nerve-sbeath staio, tbe majority of the fibres were seen to retoin the myelin sbentb, approximntely ooe-tbird of them only being nffected by degenerative processes.

Somsrazy. Microzcopic examination sbowed : 1. Parencbymotous degencration, varying in extent, of the peripberal nerves, present to a greater or less extent in all the nerves examined..

2. Degenerative changes in the large ganglion cells of the anterior borns of the cord, witb destruction and fragmentation of the protoplasmic granules and loss of the nuclei of the cells.

3. The nerve-cells of otber portions of the gray motter of the cord, medulla, brain, and spinal ganglia unchanged.

4. No change of the white motter of the cord.

5. Ahsence of micro-orgaoisms in the tissues.

Anatomical Diagnosis. Broocbo-pneumonia and bemorrhoge of the luogs. Enlargement of the epleen. Congestion of the kidneys. Congestion of the brain and cord. Porenchymatous degeneration of peripberal nerve and motor cells of cord.

After Landry'e original puhlication, there were puhlished in the eome year hy Kussmoul some similar observations. Yet neither of these papers attracted much attention until Pelegrino Levi in 1865 publisbed another paper upon this disease, and ascrihed the death of the celehrated zoōlogist Cuvier, who had died of an acute descending paralysis, to this cause.

In 1871 Bernhardt expressed the opinion that the disease was due to n poison. This conceptioo that Landry's paralysis depended upon un intoxicatioo was accepted hy Westphal, who in 1876 cbaracterized the 
disease as one with a progressive, ascending, funlly fntal course, with retention of the-electrical irritnhility of the paralyzed muscles, with negative results npon nutopsy. This conception of Westphal was soon very much widened, nnd numerous cases vere reported from nll sides, which varied in the widest way from the descriptions hitherto given of the disense.

In 1889 Ross, in a series of articles, maintnined that this disease was identical with periphernl neuritis. This view was nlso held hy Nuuwerck nnd Barth, in a paper puhlished by thein in the same year, and has been the cause of uumerous discussions gince. The enrlier autopsies gave generally negntive results, hut, as time went on, those in which pnthological chnnges were found hegan to he more numerous, and it mny he assumed thnt the previous failures to find pnthological chnnges were in mnny instances due to imperfect methods of exnminntion.

Again, the great diversity of lesions descrihed can undouhtedly he explained from the fnct that mnny writers included cases which probahly helonged in classes by themselves. Many of Ross's cases, for instance, must certainly he considered as cases of peripheral aeuritis, nad the sams is trus of mnny other cases which hnve been puhlished as Lnndry's parnlysis. On ths other hnnd, cases have heen published and included in tahles where the lesion vas a diescminated or localized myelitis or $\mathbf{n}$ general central myelitis. Thereforc, in the discussion of the pathological changes in Laadry's diserse, many cases which havs been published under this title have heen omitted, for reasoas which seem sufficient. No attempt has heen made to examine cases where a pathological examiantion was aot made.

Among the cases which have heen reporter where the pnthologieal examination resulted negatively was the original one of Landry, where there was said to have heen coagestion of the memhranes, hut no lesion in ths brain or cord. The periphernl nerves were not exnmined.

In Pelegrino Levi's case the nerve-roots, spinal ganglia, vagi, cord, sympnthetic nnd pneumogastric nerves were normal. In the second ease reported hy him, thnt of Baron Cuvier, there was no examinntion made.

Oulmont and Hnyem ${ }^{3}$ found in their case the spleen enlarged nnd a slight injection of the pia in the upper pnrt of the cord; the gray matter of the cord reddened, and congestion of the capillnries. After hurdening in chromic acid, there could be found no npprecinhle niteration anywhere. The muscles microscopically were irregularly striated nnd in places waxy degenerated.

\footnotetext{
1 Landry. 8 ar la paratysíe ascendante aigai. Gar hebdom., 1850, rol. vi. p. 472.

- Pelegriuo Lavl. Contribution $a$ l'étude da le paralysie escendante algué, elc. Arch. gën. de med., 1605, 6 serie, vol. 1. p. 129.

I Onlmont and Hayem. Paralysíe ascendante ajgue, Gaz, đes hôp., 1867, rol. xl. p. 405.
} 
G. Hnrley and J. Lockhart Clnrke found congestion of the vessels of the cord nnd of the pia, with a softening of the nnterior column, which involved the anterior nerve-roots, and more or less of the gray mntter of the cord. The medulln nppeared normnl.

M. Bernhardt ${ }^{2}$ found the hrain, medulla, and cord nornnl. The vngi, eciatic, nnd sympathetic nerves were also normal. The specimens were examined after hnrdening in Minller's fluid, and fresh. No cultures were made. There was ncute hyperplastic splenitis.

C. Westphal ${ }^{3}$ reportcd four cases. In the first there was hronehitis, nnd tuherculosis was found in the lungs. The spleen was enlnrged. The cord nnd medulla stnined with carmine were normpl.

In his second case the spleen ras found slightly enlarged; the hrain, cord, nerve-roots, ganglia, and museles were normal ; mndernte degeneration of one of the crusal nerves was found. There were no hncterin present in the hlood.

His third nnd fourth cases prohnbly do not come nnder the head of this disease of which we are epeaking.

$O$. Knhler and A. Pick' found an ncute hyperplastic splenitis. The cord was normal. There were adhesions hetween the spinal dura nnd pia. The nerves were not examined. The specimens were stnined with carmine after hordening in Mrüller's fluid.

H. Kümmell' found enlargement of the spleen. The cord wns exnmined after hardening in Müller's fluid nnd staining with carmine, hæmatoxylin, nnd methyl-violet. The cord was normal. The peripheral nerves were not mentioned. There was a hilnteral henorrlnge in the medulln, without nny infiltration of the tissues in the neighhorhood with leucocytes. This patient had died of parnlysis in the fourtl reek of typhoid, nnd the chnracteristic lesions of typlooid were found in the intestines.

A. Strümpell, in his case, reports enlargement of the spleen, nnd that the cord, microscopically, was not pathological. The peripheral nerves were not examined.

In Mnnn's case ${ }^{\top}$ the spleen was not enlnrged ; the cord, medulla, nnd hrain were normnl. The peripheral nerves were not exnmined.

1 Fingles and Clarke A Fatal Case or Acute Progresive Paralysis. Lancet, 1863, rol. It. p. 451 .

1 Bembarde. Beitrap zar Lehre von der acten allgemelnen Paralyse. Berijn. k1In. Woch.,

187. Yol. vil. p. 561 .

vol. vl. p. 765 .

Kabler and Plck. Zn der Lebre ron der acuten entstelgenden Paralyse. Areb. I. Psych.,
1880, vol. x. p. 313 .

- Kammell. Zur Lebre von der acoten aurstelgenden Splalparalyse Zeltsch. f. klin. Med.,
1881, vol. fl. p 272.

Etrumpelt. Zar Kenntuiss der maluplen degenerauren Neurits. Areh. f. I'sech., Iss;,
rol. xlv. p. 3i3.

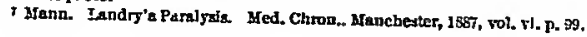


Greppin, in his case, found the brain, cord, peripheral nerves, the spinal ganglia, and nerve-roots healthy. Cultures were aegative.

J. A Ormerod ${ }^{2}$ reports three cases. Ia his first the spleen was lnge und soft. The brain, sciatic and vagus nerves were normal. The stnins used were Weigert's, picrocarmine, nad aniliae blue-hlack. The cord, stained with carmine, Pal'a stain, aniliae hlue-hlnck, also showed no chnnges. In his second case the spleen was also ealnrged. The cord, hardened in Müller'a fluid and stained in nniline blue-hlack, showed no changes. The aaterior tihial nerve, hnrdened in Müller's fluid, and the caudn equian, hordeaed ia osmic acid, were hoth normal. In the third case the spleen is reported as rather larger than aormol. weight tea and a half ounces, and soft. The nerves, treated with osmic acid aad MIulli:r's fluid and staiued witb picrocarmiae or Pal's stain, showed nothing nhi:ormnl. In one vagus nerve, however, some of the fihres seemed to take Weigert's stain more deeply thnn they ought. The cord, stained with picrocarmiae, aniline blue-hlack, and by Pal's method, was aormal.

J. Watsoa, ia bis case, reports the membraass of the cord sligbtly congestcd, and says that no cbanges noticeable to the naked eye were preseat. He also adds that sections of the cord were bardeaed and examiaed microscopically, but threw no ligbt upoa the pathological changes.

A. Albut reports ia his case the spleen of normal size and coasisteacy. The menbraaes of the cord were iajected to a moderate degree. The cord was aormal. The brain was rich in blood, and showed small bemorrhages ia places. The cord was hardened in Müller's fluid and stained with carmiae, aigrosin, aad Weigert's stains, aad showed nothing microscopienlly, and tbe bacteriological and microscopical examiuation of the crural and axillary nerves was negative. Cultures made from the hlood, spleen, nnd cord were also negntive.

Voa Leuhes reported a case in which the cord and peripheral nerves showed no changes. They were hardened in Mrüller's fluid.

II. Priace reports a case in which the cord was microscopically nor$\mathrm{mnl}$. The nerves of the hrachial plexus, stained by Weigert's method, showed no clinnges.

B. Robiason' reports a case ia which the spleen was normal. In the

1 Greppla. Correspondzbl. Aur schwelzer Aerzte, ISg, vol, xxil. p 517.

Ormerod. Illustrations of Landry' Paralssis. St. Barth. Hosp. Reports, 1892, rol. xxvli. p. 137.

3 Watsou. Acute Ascending (Iandry'a) Paralysix. Drtikh Med. Journ., 1892, vol. If. p. 1286.

- Alhr. Znr Aellologie der Paralysta ascendens acuta, etc. Zeltschr. f. kiln. Mred., 1993, vol. xili. p. 387.

- Von leube. Dlagnose der Innereu Krauthelten. Leipzig, 1883, rol. 11 p. 143.

- Prince. A Case of Landry's Paralysis with Autopyy. Jouru. of Nerr. and Ment. Disense, 1895, vol. xx11 p. CS6.

T Roblnsou. A Case of Lundry'a Paralysis. Med. Rec., 1895, vol, IJill. p. 5it. 
hrain and spinal cord the hlondvessels appeared somewhat congested, hut there was no softening. The cereh ral convolutions were flattened, more especially over the right parietal lohe, where there was some hulging. In the right parietal lobe $\mathbf{n}$ tumor, two and one-half inches in diameter, firmer than the hrain tissue, hut rather soft, was found. This was found to he $\mathrm{n}$ spindle-cell sarcoma. Sections of the cord stained hy Weigert's hæmatoxylin, Delafield's hematoxylin, and Van Gieson's stain showed no lesion, either infinmmatory, degenerative, or of other nature.

This completes the crses found in the liternture where the microscopic examination showed no changes. The cases in which changes have heen found, but in the peripheral nerves only, or where the changes in the cord were so slight that no importance was nttached to them hy the writers, are the following :

Dejerine and Goetz ${ }^{1}$ found in the cord, hardened in chromic acid and stained with carmine, no changes except that the vessels were somewhat dilated. In the nerves they found degeneration of the nerve-fibres, with increase of the nuclei of the neuroglia, in some of the anterior nerve-roots.

F. Eichhorst found the spleeu smnll; the hrain aod cord normal. The optic nerves aud the optic chissm were red in color. The periphcral nerves showed evidences of neuritis. This case, clinically, showed a marked diminution of sensation, with pain and tenderness in the extremities, and probahly helongs to the cases of peripheral neuritis, ns there were no hulbar symptoms. The case developed three weeks after an attack of malaria.

Dejerine $e^{3}$ reported a case in which the hrain and cord were negativc; hut there tere alterations, which he considered of a parenchymatous nature, in the nnterior nerve-roots nnd in the intramuseular uerves.

Curschmann ${ }^{4}$ reports $n$ case in which the spleen was four times the normal size. The intestine showed the charncteristic changes of typhoid fever, from which the patient was suffering. The hrain was normal in appearance. The pia of the cord was hyperemic; the cord was said to he otherwise normal, except in the lumhar region, where the gray matter was slightly reddened. Upon microscopical examination of the cord a few small areas were seen in the lateral columns, which showed " a sort of swelling with thinning of the axis-cylinders," hut no complete destruction of them. The cultures from the lumbar nnd dorsal cord were negative. Cultures from the upper dorsal and cervical cord and spleen

\footnotetext{
1 Dejerine and Goetz. Note str un cas de joraljgle ascendante aiguë. Arch. de physiol, 1876, 2 serie, val. III. p.s12.

Elchhorzk. Nenritis acuta prognessira Vrch. Arch., 1876, vol. Irlx. p. 265.

a Dejerne. Becherches anr les lfsions du gyridme nerverse, Paris, 1879.

- Caruchmenn. Bemerknngen uber dis Verbajten des Ceutralnerrensyatems bel acnten Infectlonskrankhelten. Verhnndiungen des V. Congreses fur lnnere Med., I886, vol. v. p. 469.
} 
showed the presence of the typhoid hacillus, which was also demonstrated hy inoculations. Bncilli were found in the sections of the cord only in the white suhstance of the cervical and upper dosal regions.

A. Nnuwerck and W. Barth ${ }^{2}$ reported a very typical case, except that the duration was somewhat prolonged (three months). The cord, hardened in Flemming's solution, as well as the medulla, showed no changes. The peripheral nerves showed a moderate degeneration. The lungs were the seat of - $n$ heginning tubereulnr process.

Ross found the internal, antero-lateral, and postero-lateral groups of nerve-cells normal, while the central nnd median were diseased. There was " granular degeneration of the nerve network," with disappearance of the ganglion cells and increase of the nuclei, together with dilntation nnd congestion of the hloodvessels. In his second case hs could discover no trace of disense in the cord. In an article published lnter, ${ }^{3}$ in speaking of his first case, he says thnt after further study he cams to the conclusion that the changes in ths gray matter of the opinal cord wers a minor matter.

C. Eisenlohr,' in his case, reports the spleen very large, containing no infurctions. In the ileum there were hemorrhages and swelling of the follicles, with enlnrgement of the mesenteric glands. Tho hrain, cord, nnd medulln, stained with borax-carmine, nigrosin, and Weigert's stain, showed no chnnges. There was degeneration of the hulhar and peripheral ncrves. Cultures were negative as regards hncteria, as well as smears upon cover-glasses, nnd the sections.

In his second crse he found nbundnnt eerum in the spinal cannl and the pin slightly œdemntous. The spleen wns not enlarged, hut there was slight swclling of the mesenteric glands and of the follicles of the ileum, where twere nlso found tubercular ulcers. The cord in the eleventh und twelfth dorsal segments ehowed swollen axis-cylinders in the lateral columns nnd degenerative products of the medullary gubstnnce. The gray matter was normal. He described this as nn acute myelitis. The stains used were nigrosin, carmine, picrocarmine and hxmatoxylin. The right vngus was slightly degenerated; the left one normnl. The lower cervical and upper dorsal anterior roots showed signs of degeneration. The nnterior roots of the lumhar enlargement showed an increase of cells of the connective tissue nnd adventitia, hut no degen. eration. There was no degeneration present of the sncral roots. Ths right tihial nerve was degenerated. Cultures showed two organisms. The first was found in the cord, the spleen, the sciatic nerve, and was the ataphylococcus cereus albus. The second organism was found in

\footnotetext{
1 Nanwerck and Barth. Znr palh. Anatomle der Landry'sehen Lihomnog. Zieg. Beltrïge
zur path. Anat, and allg. Path., Jenn, 1889, vot. v. p. 1.

2 Ross. Disenses nf lhe Nerrous 3 sstem, second ediuon, New Yark, 1883, roL. 1. p. 008.

- Bass Perpheral Neu rits, Mled. Chron., Manahester, 1889, val, x. p. 376.

1 Fisenlohs. Ueber Landry'sche Paralyse. Deat med. Woch, IB90, vol. xrl. p. 84.
} 
the spleen and scintic nerve only, and was the staphylococcus pyogenes aureus. No tuhercle hacilli were found. In the sections there were found a long and short hacillus and a coccus.

Hun' reports in his case a slight cerebral and spinnl meningitis, with infiltration of the walls of the epinal veins. Aside from a degeneration of some fibres of the antarior roots of the cauda equina, the nervous system was normal. No hacterin were found in the tissues, nnd cultures made from them were negative.

E. Centanni2 reports in. his case that the vessels in the nerves were engorged and the walls were somewhnt infiltrated. The nerve-fihres were not much altered. He designates the process as a slight degenerative interstitial neuritis. The cord showed congestion in the vessels of the pin, exudation about the central canal, and some atrophy in the peripheral zone of the cord. Other parts were normal. In the periplieral nerves he found a slender hacillus, with rounded ends, without spores or chnracteristic grouping. These were usunlly present in the endoaeural lymph spaces. These bacilli were not found elsewhere. No cultures were made.

Giuzetti ${ }^{1}$ found the spleen large and soft. There was zome disintegration of the nerve-fihres of the cond, which was nuost marked in the lumbar region; ahsent in the medulla. The ganglion cells were cloudy, with indistinct nuclei. About the vessels tbere was n ring of granulnr substance not staining like fibrin; there were nlso recent punctiform hemorrhsges in tbe medulls and pons. Tbere was degeneration of both anterior and posterior nerveroots, but most mnrked in tbe nnterior ones. In the peripheral nerves there were multiplication of the nuclei and infiltration of some of the vessels. No hacterin were seen in the sections. Cultures made from the brain, cord, scintic nerre, blood, spleen, mesenteric glnnds, and urine were all negative, except two tuhes from the sciatic nerve and one from the cord, upon which grew a chromogenic bacillus. A rahbit injected with an emulsion of the spinal cord nnd spleen gave negative results.

The following are the cases fonnd in the literature in which the changes in the cord were marked, whether or not degeneration of the peripheral nerves was found :

P. Bau mgarten' reported in 1876 a case which is interesting as hnving heen the first in which hacterin were found. These hncilli he identified as the anthrax hacillus. They vere found in the lungs, in the spleen,

1 Hun. The Patbol. of Acnle Ascending (Lsudrg"s) Paralgal. New Yurk Med. Jonra., 189L, vol. IIIL, $\mathrm{p}$ co9.

a CentannL. Etn Yall ron Landrg'acher Paraljse Ztegler's Beltrige anr path. Anat. $a$. allgem. Path., Jen 1890 , vol. vill. p. $35 \mathrm{~s}$

Gluzett. Ruform, 3red., 1891, vul. U. pp. 5, 19, nnd 3L. Quoted by Bdhey and Ewlng.

1 Banmgarten. Eln efgethumitcher Fall ron Paralyale ascendaute afgü mit Plibblidung in Blut. Arel. I. Hellkunde, 1876, vol. xvil. p 215. 
the spinal cord, and the blood. Cramer, in his review of the literature of Landry's paralysis, questions whether this identification of the hacillus found would be accepted at present. Baumgarten found a hyaline substance in the gray matter of the cord, in the commissure, the anterior fissure, and in the perivascular spaces, which he considered an inflam. matory exudation. The vessels were distended with hlood, and some were filled with pus-corpuscles.

C. Eisenlohr' found in his case the spleen enlarged and soft. The gray substance of the spialal cord was hyperemic. After hardening in Müller's fluid the cervical cord showed erudation ahout the central canal and the ressels of the gray matter and in the anterior fissure. The nerre-cells were filled with granular pigment. These changes dimiaish hoth nhove and helow, hnt the same appearances were found in the upper lumhar cord. The medulla ehowed cellular infiltration ahout the ressels, and the ganglion cells were swollen and shining, and here and there were capillary hemorrhages. The peripheral nerves were normal.

Schulz and Schultze reported a case which is prohahly to he regarded as transitional hetween the typical cases of Landry's paralysis and the paralysis of Duchenne, in that the course was rather loag (sixty days). They found degenerative processes in the lateral and pyramidal tracts, us also in the posterior columns. There was inflitration ahout some of the vessels. There were alterations in the gray matter in the anterior horns, particularly in the lumbar region; the ganglion cells were swollen, granular, and vacuolated. Swollen axis-cylinders were seen in the gray matter and also in the anterior roots. The enme changes, hut less intense, were found in the dorsal and cervical cord. In the posterior nerve-roots of the lumbar and cervical cord there was seen an occasional swollen axis-cylinder. These ahnormal axis-cylinders were also seen in the facial nucleus; otherwise the medulla was normal. There were no hacilli found in the hlood. They summed up the changes as consisting of a myelitis of the motor tracts and of the anterior gray substance of the whole cord, and of the lower part of the merlulla. There were slight degenerative changes found in the sciatic, ulnar, and peroneal nerves.

Among these cases, in which changes more or less extensive were found in the spinal cord, we must mention two crses reported hy Aufrecht. There the changes found keemed more like a localized myelitis than the changes in the cases already quoted. In the first case, in the medulla, helow the olive, the central part for the distance of a quarter

1 Elseulobr. Ein Fall von Paralyis ascendens acuta. Virch, Arch, 1878, vol. 1xxHI. p. 73. Scholy and Schultze. Zar Lehre vou dez acuten aulstelgeuder Paralyse. Arch. f. Paych,
IBS2, vol. xil. p. 157.

* Aufrecht. Pathol. Mitthellaugen. Hsgdeburg, I881. 
of an inch was cloudy. Microscopically, uumerous large fnt-granule cells were found. In the second case, nt the upper and middle third of the cervical cord over $\mathrm{n}$ space of ahout $2 \mathrm{~mm}$. in length, were found several small spots, the size of the head of $n$ pin, which upon microseopic examinntion was seen to he filled with granular detritus, n few red hlood-corpuscles, and hodies resemhling corpora amylncea.

Roussel ${ }^{1}$ found vascular lesions in the cord, with degeneration of the ganglion cells. The peripheral nerves were not examined.

J. Hoffmnnn ${ }^{2}$ found the memhranes of the hruin and cord much congested. In the medulln there ras infiltrntion of the vessels of the meninges and nerve substance. In the corpus restiformis and pyramids there were occasionally swollen axis-cylinders. There was slight extravasation of the red corpuscles throughout the whole of the medulln. The infiltration in the cervical nnd dorsal cord was more marked. In the lateral columns of the cord there were smail groups of swollen axiscylinders. The same thing was true of the nnterior roots. Tlie ganglion cells were shing and swollen, with indistinct nuclei. Small hemorrhages were seen in the cord, and particularly in the gray substance in the cervical and dorsal cord. The crural and left facinl nerves were normal. The right facial nerve showed degenerated fihres. The examination of the blood for bncteria was negative.

Immermann ${ }^{3}$ reports a case in which the patient died of pneumonin four weeks after the development of the paralysis. The brain, peripheral nerves, nnd muscles showed nothing. The anterior horns of the lumhar, dorsal, and cervical cord showed numerous reddish spots. On examination, the ressels were found filled with red corpuscles, and granular cells infiltrated the perivascular spaces. The ganglion cells were replaced in part by hyaline masses. The white suhstance of the cord was not affected.

Ketli' reported $n$ case in which he saw changes in the spinal cord which were those of acute nnterior poliomyelitis.

Iwanows found the vessels of the spinal cord enlarged, as well as the capillaries of the gray matter, especially in the anterior horns. There were some capillary extravasations. The walls of the vessels were infiltrated. Similar changes were seen nhout the central canal, where there was also a fihrinous exudation. The nerve-cells nppenred cloudy and swollen, and many of the nuclei were lost. The cord was hardened in Müller's fluid. The examinntion of the cord for hncteria hy Gram's stain resulted negatively.

\footnotetext{
1 Rousel. Arch, de med, nsq., 1883, rol xxxlr. p. 370. Quoted by Balley and Ewing.

Hofrmann. Edn Fall von acuter aufsteigender Paralyse. Arch. f. Psyeb.,I8s4, vol xv. p.140.

- Immerminn. Ueber Pollorayelits ant acute und Labdry'sche Paralyse. Neurolog. Centralbl., I885, vol. I7. p. 304.

4eLli. WIen. med, Blatt, 1857, vol. $x$ p. 250. Quoted by Balley and Eiving.

I Imanow. Zwel Fxile von acuter anfstejgender Bplas] paralysc. BL. Petersburg.med. Woch., 1888, vol, 7. p. 395.
} 
J. J. Putman' also found acute hyperplastic splenitis. The peripheral nerves showed signs of neuritis, and there was infiltration of the nerve-roots. The hloodvessels were crowded with hlood. The perivaseular spaces and the central canal of the cord contained a " modernte number of cells." The nerve-cells were esseatially normnl. In the white mntter of the cord an occasional enlarged axis-cylinder was seen. In the medulla the vessels were engorged, and there was infiltration of the perivascular spaces, and occasionally slight hemorrhages.

R. T. Williamson ${ }^{2}$ reports a case in which the paralysis began in the right hand, extending later to the left, and then to hoth legs. There was no disturhance of seosation; reflexes were nhseat; there was rapid ntrophy of the muscles. After the first ten days the patient began to improve slightly, but died suddenly from some unknown cause. In the examination of the cord, in the outer part of the anterior horns, the gray matter was found infiltrated with small rouad cells, and some larger cells evidently containing myelin. The hloodvessels in the neighhorhood were dilated and the perivascular spaces filled with round cells. There were no resl hemorrhages. The nerve-cells were shruakea and had lost their processes. There was an ahsence of the normal aerves seen in the anterior horns, though these were present in the other parts of the gray matter. The remainder of the cord was normal, except that the hloodvessels were dilated, and there wcre infiltrations ahout some of them. There was an atrophy of the anterior nerveroots. The posterior nerve-roots were normal. The pia was normal except for dijatation of its ressels and occasional round-cell infiltration at the anterior part of the cord.

E. Klebs' reported a case in which there was tuhercular pericarditis from a small cheesy hroachial gland. The ouly change found in the aervous system was $n$ hyaline thrombosis of the ceatral arteries of the cord, with microscopical hemorrhages ahout these vessels and about most of the nerve-cells, consistiag of n moderate or a greater number of round cells, with siagle large auclei. Klebs ascrihed this thrombosis to nn acute infection.

Hlava found the brain and cord normal macroscopically. Upon microscopical exnmiantion the gray substance of the cord from the lumbar region up to the medulla, the poas, and corpora quadrigemina was the seat of small cell infiltration nnd hemorrhages in places. The

\footnotetext{
1 Putman. A Cesse of Acute Futal Feurtts of Iufectlons Origin. Boston Med. and Surg. Jotum., 1889, cxx. pp. 159 and 187.

? WIItiamson. The Early Changes in the Eplaal Cord in A cule Ant. Pollomyelitis of the Adult. Med. Chron., Msuchester, 1890, vol, ril. p. 454.

z Klebe, Ueber Laudry'sche Paralyse. Deutsch, med. Woch., 1891, vol. Ivil. p. $\$ 1$.

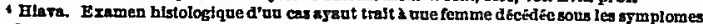
de If paralysie de Laudry. Arch. boh. de med., 1891, vol. Iv. p. 970. Ref. In Schmldt's Jabrbuch, 1891, vol. cexrrll. p. 214.
} 
foci were chiefly in the anterior nnd pnsterior horns nud also in Clnrke's column. The white suhstance was intrct. The vessels everywhere were dilated. In the medulla the infiltration involved chiefly the nuclens of the vagus, hypoglossus and glosso-pharyngeus, and also the olives. The sciatic and the ulnar nerves were exsmined. In hoth there were numbers of so.called mast-cells in the medullary sheath, hut nowhere was there degeneration.

Zusch ${ }^{1}$ repurts a case in which a change in the color of the white suhstance of the cord was evident-a change which " would indicate nn acute myelitic process." The cord seems to have heen exnmined macroscopically only. The paralysis seemed to he the sudden outcome of a very marked stage of chronic alcoholic poisoning.

E. Leyden ${ }^{2}$ reports a case where the spleen was small and firm. There was hroncho-pneumonis. The hlood contained no hacteria. There was neuritic ntrophy in the peroneal nerves, in the right radinl, and in the recurrent nerves. The cord, hnrdened in Müller's fluid, showed some thickened and swollen nerve-fibres, with poorly-staining sheaths. These were most abundant in the lateral columns of the dorsnl cord, diminishing nbove. Between these large fibres were smnll ones, which Leyden thought compressed. Deiters' cells were enlnrged, swollen, with clear nuclei, hut not increased in number. There were no compound granule cells. The ganglion cells of the anterior horn wero swollen and cloudy, so thnt it was difficnlt to make out the nucleus, and the nerve processes were swollen. In a considerahle numher of these cells vacuoles were seen.

W. Oettinger and G. Brarinesco reported a cage in which the dorsal and lumbar cord was very soft, with injection of the pia; nhove, the cord was fimer. The mednlls and hrain were congested and contained small bemorrhages. The changes in the cord followed the vessels of the anterior fissure principally. The vessel-walls were infiltrated, and the vessels themselves contained thromhi. Occasionally there would be a rupture of the ressel with a small hemorrhage in the gray matter. The nerve-cells showed loss of the protoplasmic granules, rupture of the cell processes, and also true atrophy. The changes were less marked in the cervical cord, where they were practically limited to the anterior horns. The snme was true of the medulla, where, however, the affection of the nerve-cells was less. Bacteria, mostly streptococci, were seen in the leucocytes and occasionally in some of the nerve-cells, and a diplococcus was also seen. No cultures were made.

1 Zusch. Inaug. Dies. Jenk, 159L. Quoted In Bsjoun' Annanl of Universal Med. Bci., 1896, vol. 11. B. 18.

2 Leyden. Ueber malt. Nearitis and acate surstelgende Pantyse nach Inflnenza. Zeitschr. $f$. vlin. Mred., 189, tol. IrIv. p. 1.

I Oeltinger and Marinesco. De l'origine infectlense de la paratyale ascendisnte algan, etc. gem. m6d., 1895, vol. xv. p. 45. 
G. Ballet and A. Dutil, ${ }^{2}$ in their case, reported that microscopic examination of the cord striaed with hamatoxylin and eosia showed an enormons dilatation of the vessels of the cord, especially in the anterior horas. The perivascular lymph spaces were infiltrated with leucocytes, nnd there were occasional hemorrhages. Nissl's stain showed pronounced degeneration of the cells of the posterior horns, of the columns of Clarke, and particularly of those of the anterior horns. These changes consisted of the disappearance of the protoplasmic granules, a swelling of the cells, the separation or rupture of the processes, disappearance of the nucleus, nnd granular atrophy. These changes were less marked iu the medulla. The peripheral nerves showed heginning degeneration. There was little change in the muscles. No hacteria were ohtained from cultures, nor were they present in the sections. There was exteasive fatty degeneration of the cells of the liver.

P. Marie and G. Marinesco ${ }^{2}$ reported $n$ case in which the veins of the pin of the cord were injected. On section the anterior horns were soft and injected. The medulla wns more normal, hut here there were very evident hemorrhages in the gray substance of the floor of the fourth ventricle and among the root-fihres of the pneumogastric, and occasionally among the hypogloseal fibres. In the hrain there were slight pin-point hemorrhages in the gray matter. On microscopic examiantion of the cord the anterior horns were found to he made up of mononuclear leucocytes, so that the appearance was almost that of an ahscess. The leucocytes were disposed chiefly nbout the hloodvessels. The posterior horn showed only slight infiltration and congestion of the vessels. The nerre-cells, where not completely destroyed, were swollea, and showed loss or fragmentation of the protoplasmic granules, and rupture of the processes from the cells. In the cervical region these changes were less marked, nnd the same was true of the medulla. A hacillus from $5 \mu$ to $12 \mu$ in length, articulated end to ead, with a clear space hetween -them, with slight enlargemeat of the free ends, was found in the vessels of the nnterior horn, nnd rarely in the nerve-cells. In the lumbar region this bacillus was not found, hut $n$ much sliorter organism. presenting the form of a "diplo-hacterium." No cultures. No inoculations. The peripheral nerves seemed normal.

Remlinger reports a case in which he fonnd dilatation nnd inflammntion of the vessels of the nnterior fissure, nnd particularly of the hrasches to the anterior horns. The leucocytes were more numerous in the vessels than normal. He speaks nlso of the rupture of the cell-

1 Ballet and nntil. Paralgsio ascendate algut symptomatlque d'nne myclite difruse ascendante. Bult. et mem. de In soc. med. des bop. de Parls, 1895, se serfe, vol, xu. p. 6S4.

- Marle and Brarinesco. Snrnn cas de paralysfe de Landry, etc. Bnll, et mém. de in soc. m6d. des büp. de Parls, 1895, 3e s6rle, vol. xłl. p. 659.

- Remunger. Eur un cas de maisdite de Landry, etc. Compt rend. de in soc de biol. Parls, 1890, loe eurie, roi. Ill. p. 376 : also Mled. mod., PaHs, 1606, vol. vil. p. 209. 
processes of the ganglion cells. Nissl's metliod was used. In the nuterior horn in spaces hetween the large cells, prohahly in the lymph spaces, he fou od chnios of streptococci. There vere no hacteria within the nerve-cells. There were no hæmatozoa in the vessels or out of them. The medulla and peripheral nerves were not examined. Pure cultures of streptocsccus were ohtained from the cervical, dorsal, nnd lumbar cord. The hlood from the peripheral vessels was sterile.

P. Bailey and J. Ewing in their case reported the spleen as enlarged. They found congestion of the hloodvessels of the cord, with exudative inflammation in the noterior horns of the cord nnd in the medulla. There were pascular und exudative changes in the motor cortex, the hasal ganglia, nnd the cerehellum. There were degeneration of the nerve-cells and vascular chnnges in the nerve-roots. The peripheral nerves were not examined.

J. Eichherg' in his case found congestion of the anterior horns of the cord. There rere hemorrhages into the anterior lorn, and the tissues nhout the vessels were infiltrated with round cells. In the lumbar region ths process nmounted practically to nn ahscess. Io this portion there were no ganglion cells. Higher up in the cord some of ths ganglion cells remnined, hut were altered nad surrounded by inflanmatory exudation. The alterations were shown by the difference in staining with anilins blue-black, Weigert's, and other stains. There were no clanges in ths white matter except congestion of the vessels. This memhranes of the cord were congested. The anterior nerve-roots were normal. The hrain and the peripheral nerves were not examined.

Diller and Meyer' reported n case of Lnndry's paralysis which was normal except that the course was somewhat prolonged (fourteen weeks). They found a diffuse atrophy in the pyramidnl tracts, with hyperamia of the crossed pyramidal tract and increase of the neuroglia. The axiscylinders of the pyramidal fibres were slightly rarefied. In the nnterior horos there was marked pigmentation of the ganglion cells. The nerveroots were normal. The medulla, hrain, and peripheral nerves were not examined.

R. Von der Velden" reported a case which is not perfectly typical. In it he says that the legs were stiff, nnd there was a loss of the electrical excitahility of the muscles. The cord showed swelling of the axiscylinders, witl loss of the myelin sheath in vnrious sinall nreas, chiefly

1 Balley and Ewing. Contributlun to the Study of Acuto Ascending (Lendry ${ }^{\circ}$ ) Paralysls. Nesr York Med. Jutri, 1896, rol. Ixiv. pp. 1 and 11.

2 Bichberg. A Cuse of Ascending Paralysts, etc. Med. Ree, New Yark, 1891, vol. xxxix. p. 226.

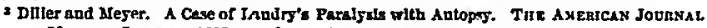
OP THE NEuical SCINsces, 1896, p. cot. p. 401.

4 Van der Velden. Ein Fall run acuter antstelgender splnal Pamlsse. Deutsch. Arch. $f$. kllu. Med., 1877, vol, x1x. p. 333. 
it the anterior and lateral columns. There was nlso some exudation about the vessels. ${ }^{1}$

From a cursory review of the changes found in these autopsies one would nlmost think that nny possible change of the nervous system could cause Landry's paralyais, or no changes at all be required to produce the aymptoms. It would hardly seem that it were merely accidental that so many of the cases with negative pathological examination were among the first reported. Without douht many of these cases if cxamined with the present methods would have shown definite pathological processes, so that it could scarcely be maintained hy any one at the present day that Westphal's criterion of $\mathbf{n}$ negative pathological result is necessary in this disense.

Leyden divides Landry's paralysis into: 1. A hulbar or medullary form. 2. A neuritic form. The first, he says, is caused hy a process in the cord which extends to the medulla, and is essentially a myelitic

1 The case of Varnaij, In the Romania med. Bnenresel, 1896, rol 17. p. 29, has been omitted because wc wera unable to obtain access to the journal; the case of Brtstor and Borstey,

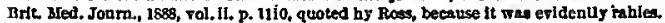

The following cases, wlth autopes, have also bean omitted for varions reaspons-a few beeause the pathological examinatlon was indefulte; most of them because the cases were not typical of Iandry's paralyals.

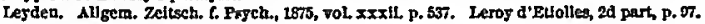
Quoted by Rosy.

OIIfler. Traits des malsdies de is moelte fninlere, 153, 3d ed., p. 51. Quoted hy Ross.

Kussmanl. Zwel Falle von Paraplegte, etc. Eriangen, 1859.

Iendet. Paralsale ascendante afgut. Gaz des hôp., 1861, vol. xxxî. p. mo.

Bahlon. Paralysle ascendante alguil. Gaz hebdom, 1861, 20 serit, vol, I. p. 806.

Lendet. Sur les trouhies des nerfs pofiphtiques. Arth. g6n. de méd., 1865, be sitie, rot. 1. p. 505 .

Boundilat. Pardsale gen. consecnt res a is rongeola. Gaz, des höp., 1868, rol, xll. p. 5.

Chalvet Thise de Perds, 1872 ; also Gaz des hop., 187, woL xliv. p. 369.

Duchenue. De l'électrisatlon locallse, 1872, 3d ed., p. 4t5. Qnoted hy Rosi.

Gombault. Un cas de paralyste splasl. Arelt. de phys., 1873, vol, ₹. p. 80.

Cornll and teplne. Soc. de hlologie, 1873, vol, 7. p. 206 .

Caiestr. Gar Lomh., 1874, vol xxxir. p. 20; also in Echmidt's Jahrhnch, 1875, vol. clrvlli. p.18.

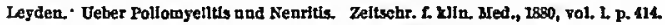

Fox. A Case of Acnte Ascending Panatysis. Brala, 1850, rol, 1L. p. ItB.

Fiuny. A Case of Acnte Ascending Puralynis. Brtish Sfed. Jonro., 1892, vol, 1. p. 732.

Roth. Nenritis dEseminsta scutisgima, Correspondenzhlatt fur gchpelzer Aerzte, 1888, vol. xHI. p. 817 .

Vlerondf Mnitiplen degenerativen Nenritls. Arch. I Psych., 1B53, rol, xiv. p. 678.

Wood and Dercnm. Acute Ascending or Landry's Paralysis. Ther. Gaz, Detrolt, 1885, vol. 1x. p. 157.

Bnck. A Case or Landry's Paralyeis. Lancet, 1885, rol. IL p. 12.

Sondeykine. Arch. de Neurot., 1886; atso in CentralbL f. kiln. Med, 1887, vol. 7ili. p. I8L.

Pitres and Valland. Paralysfe ascendsute algue. Arch. de phys, 1887, 3e sérfe, vol. Ix. p. t49.

Lunz and Namnrowski. Quoted In Neurol Centralht, 1890, vol. Ix. p. 696.

Prihytkow. Boc of Neuropathologists and Alfenists at the Moscop Unlversity. Sept. 24, 1893. Nenrolog. Centraibl., 1894, vol, xill. p. 716.

Vranjlcan. Fall von acnter mulupter Feurlts. Wlen, klin. Woch., 1895, vol. vlli. pp. 485 and 5 tt.

Stephens. Landry's Paralysis, Glasgow Sed. Journ, ISBG, vol. xlv. p. 5

I Leyden. Zeltsch. f. klin. Srer., 189, vol. xxl7. p. 26; and Nothnage's Path, nnd Therap, 1897. Fol. x. p. 415 . 
process. The other form he thinks is a purely neuritic one, nnd in this case be states that changes in the electrical reactions of the nerves nad muscles often occur, so he says to the process in the second form of the disease, a polyneuritis, there is joined $n$ parenchymatous cedemntous process in the spinal cord, which extends to the medulla and, urriving in the neighhorhood of the vital nerve-centres, causes death. He also calls attention to the fact that multiple neuritis in its ordinary course shows several essentinl differeaces from Lnadry's puralysis, und mentions the fact that it usually requires less time in which to develop, that there is hut a slight tendency to spreading, and no such constant inclinntion to nffect the medulla. Be might also have called attention to the fact that multiple neuritis, whea exteading, is much more npt not to ascend ia so regular and orderly $n$ maner as Landry's paralysis.

Jolly holds practically the same view, hut thinks, in additioa, that under certain circumstances the cause which produces the injury to the nerve function can net without leaving hehind it demonstrahle microscopical alterations.

In this connection it is well to remember that Dejerine and Sotta, in n case of chronic polyneuritis of fourteen years' stauding, demonstrated pathological changes in the cells of the nnterior horn. Bnllet and Dutis" nlso reported n case of polyncuritis in which they found the protoplasm of the cells of the naterior horn stained hy Nissl's method, homogeneous and smollen, without nuclei or processes. In others the granules were diminished in number, the nuclei vere irregulnr in shape nnd often nt one side of the cell, and there was loss of the nucleolus.

Landry's paralysis must, from its clinical symptoms, necessarily he an affection primarily of the motor nenron of the first order, without involvemeat of the sensory nervous npparatus. Inasmuch as this motor neuron is hoth within and without the spinnl cord, it is not so strange as it seems at first sight that changes have heen missed in the one place or in the other. That changes do occur ia the motor cells of the anterior hom in cases of pcripheral neuritis can no longer he douhted. The question which coacerns us is whether a disense which is purely motor in type should be classed with the ordinary cases of peripheral neuritis in which sensation is usually affected. Certainly Leyden was justified, by the exclusive motor paralysis, the rapid course, nnd frequent fatal termination of this disease, in separating it from the cases of polyneuritis of more chronic course, with marked pain, sensory disturhances, tenderness of nerve-trunks, nad favorahle prognosis.

1 Jolí. Berlin. klin. Wochenschr, 1891, vol. Ixxi, p. 281.

2 Compt. rend de la Soc. de biol., 1896, 10 e atile, vol lil. p. 193.

- Ballet et Duul. Snr un cas de polyngrdte avec leslons meduliaires. Bull de la soc. m6d. des hôp., 1895, se série, rol. T1L p. 818. 
That Bernhnrdt and Westphnl were correct in their supposition that the disease is produced hy nn intoxication seems to be the general opinion. That the puthological changes found should vary in intensity and extent with the severity of this intoxication need not surprise us. The first of the two cases reported in this paper shows that acute ascending paralysis, the affection heing practically nitogether of the motor neurons, may find its cnuse in nn inflnmmntory process, most mnrked in the anterior horns of the spinal cord, with mnrked clnanges in the axis-cylinder throughout the remainder of the course of this motor neuron. The case of Schulz nnd Schultze seems to occupy a middle ground between these two forms of pnralysis. From Duchenne's purnlysis these cases nre chnracterized hy their more rapid course, nnd prohnbly nlso by $n$ slighter tendency of the process to involve the posterior roots and the sensory functions of the cord; from disseminnted myelitis hy the smnll section of the cord nttacked in its transverse section, nnd hy the nnterior horns heing affected throughout the whole length of the cord. Clinically, the cases should differ also, as certainly the cases of Leyden nnd Vnn der Velden, which are prohahly of this nnture, differ from the typical cases of Landry's puralysis.

Prnctically these cases come very near the cases of ncute anterior poliomyelitis of children, differing from them in that the process is much more generalized over the motor trecks hoth of the cord and medulla, this lntter, as is rell known, being seldom affected in the infantile form. So close, indeed, is the resemhlance, that Bailey and Ewing, in their paper, hnve included in their tables six cases reported as acute nnterior poliomyelitis occurring in children, heculse of the extent of the paralysis nnd the presence of hulhar symptoms which were severe enough to cause death. Practically, one may ndmit that they were justified in clussing these cases with the severe type of Landry's pnralysis, such us theirs, thnt of Mnrie and MInrinesco, thnt of Oettinger nnd Mnrinesco, nnd the first case reported in this pnper. Prohnbly the case of Eichherg nlso helongs here. In this severer form the process consists of $\mathrm{n}$ dilntation of the vessels, with round-cell infiltration of their walls, nccompanied by degenerative chnnges of the motor cells of the nnterior horn nnd their processes. If the pnthological process is still more ecute the nnterior horn mny almost resemhle an ahscess; the normal structure of the gray matter heing replnced hy nn inflnmmntory product, consisting of lnrge nnd small lymphoid cells, of compound grnnule cells (vesicular leucocytes), nnd the detritus of the degenerated nerve-cells nnd processes. At times bncterin of different vnrieties mny be present in this inflnmmatory process itself. More frequently, as in the cases reported in this paper, the examination of the sections for micro-organisms and of the cultures is negative.

The second case seems at first glnnce to differ entirely from the class 
of cases which we have just heen considering. The examination of the cord hy the ordinary methods shors practically no changes, and we should prohahly not go far wrong if we assume that this represents one of those cases which, in the earlier reports, have heen described as without pathological changes. Nevertheless, npon more careful examination hy means of Lenhossek's and Nissl's methods, distinet degenerative changes were found in the motor cells, as shown hy the disappearance of the chromophilic granules of the protoplasm and the changes in the nucleus and nucleolus. In hoth cases degenerative changes were found in the axis-cylinders of the peripheral nerves. Prohnhly in these cases we have again to do with a degenerative process confined to the motor neuron of the first order produced hy an intoxication of some sort. We must admit that similar changes have heen found hoth in the cells and in their processes, in crses which clearly helong to polsneuritis. The fact that the course of Landry's paralysis differs so markedly from an ordinary case of neuritis, that the sensory neuron is so little if at nll affected, and that the tenderness of the nerve-trunks to pressure is absent or slight, seems to justify us in retaining this collection of synptoms as forming a separate disesse, clinieally at least.

If this conception of Landry's paralysis as a degenerative process of the peripheral motor neuron, with or without the presence of an exudn. tive infammatory process in the anterior homs of the cord, be correct, the ahsence of the renction of degeneration in the muscles affected can only he explained hy the short duration of the disease, and the same is true of the absence of atrophy; so that one is compelled to attach less importance to the nhsence of these symptoms than has hitherto been done, while the ahsence of sensory changes acquires increased importance.

Analysis of the reported cases as to the cause shows that in a grent unany none could be ascribed, nevertheless in a considerabile number of cases acute ascending paralysis followed closely upon some infectious disease, such as smallpox, diphtheria, or typhoid. The presence of nn enlarged spleen and of swelling of the mesenteric lymph glands, which is so often noted in the nutopsies, confirms this view. It has heen said that we may expect to find some micro-organisms present in the nervous structures, hut more often it is prohahle that the micro-organisms producing the poison will he found in some other part of the hody. Inasmuch as nerve-cells react in much the anme wny to various poisons, further research will prohahly show that in these cases micro-organisms are not always present, but that the intoxication may he produced through faulty metaholism or hy the absorption of poisoas from without. That toxic substances may act in $n$ selective manner, affecting only the motor neurons, is difficult to explain, although we nre not without other instances of the sume netion, as, for example, the almost 
pure motor trouhle in lead paralysis, which, in this case, as is well known, has a special predilection for the motor nerves and for those going to the extensor muscles of the forearm.

\title{
THE USE OF ANIMAL TOXNNS IN THE TREATMENT OF INOPERABLE MALIGNANT TUMORS.'
}

\author{
By Geonoe Ryersox Fowlek, M.D.

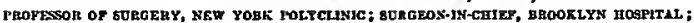 \\ SUROEON TO TIEE YETTODIST EPLSCOFAL MOSTITAL.
}

The Cure of Malignant Diseage by Accidestal Erybipelas. Early in the seventeenth century, according to Fehleisen, it was known that not only malignant growths, hut certain chronic ulcers, lupus and syphilitic destructive lesions, were nrrested, and in some instances ahsolutely disappenred following an invasion of erysipelns. In modern times Billroth called ntteution anew to the suhject, hy reporting a case of inoperahle sarcoma of the pharyax cured hy an attnck of facinl erysipelas.

There has heen some dispute as to the nuthenticity of such cases, hut it must he admitted that while it is very difficult to verify at this lnte day the assertion that all the cases denominnted true sarcomn were in reality exnmples of thnt disease, yet it is going too far to say that all of the nccounts hearing upon the question are ahsolutely untrustworthy. Nor will it guffice to declare the occurrence of the erysipelns nnd the disnppearance of the growths as merely coincidental. The theory of spontaneous disnppenrance of the growths as a coincideace in the course of or followiag an nttack of erysipelas falls at once to the ground in the face of the fact that the spontnneous disnppearance of growths which, even with the limited knowledge of pathology at the command of our predecessors, could have heen mistaken for maligant disease, is absolutely unknown. Moullin, ${ }^{2}$ in investigating this suhject in a most conservative, painstaking, and impartial manner, was ahle to identify fifteen undouhted instances of sarcoma in which nn nttack of erysipelas occurred. Of these, in no less than pine all evidences of the growth disappeared, and in some instances no recurrence had taken place for seven years. As corrohorative evidence of the influence of the erysipelas it may be said that, of the remaining six cases, fire showed a decided lessening in the size of the growth.

The cases reported hy Billroth," Busch, Biedert," Plenno," Bruns,"

1 Presented at the meeung of the Amerleau Snrgical Associallon at New Orleang, Aprll 20, 1893.

= The I.ancet, Fuhruary 5 , 1899.

3 Senn : The Journal of the American Medien Associallon, July, 1695, p. 131.

- Berllner Ellnische Wochensehrif, 1865, No. 23. D Deutsche med. Zeliung, 1\$95, No. 4.

- Archlv f. klln. Chimin., L8sG, B!t. xxxlv. p. GSs.

i Beltrage zur klln. Clifrurg. 